\title{
The Entrepreneur's Network and Firm Performance
}

\author{
Victor Nee, ${ }^{a}$ Lisha Liu, ${ }^{a}$ Daniel DellaPosta ${ }^{b}$
}

a) Cornell University; b) Pennsylvania State University

Abstract: Diverse organizational forms coexist in China's market economy, adapting and evolving in intensely competitive production markets. We examine the networks of founding chief executive officers of private manufacturing firms in seven cities of the Yangzi River Delta region in China. Through sequence analysis of ties that entrepreneurs relied on for help in the founding and critical events of their businesses, we identify three discrete forms of network governance: traditional kin-based, hybrid nonkin, and rational capitalist. We find that in traditional kin-based network governance, structural holes are linked to higher returns on assets and returns on equity. By contrast, in the rational capitalist form, structural holes and higher firm performance are not linked. We thus show that the content of the tie matters critically in the relationship between structural holes and firm performance.

Keywords: social networks; sequence analysis; organizational performance; structural hole; institutional change; organizational form

THE effect of social networks on economic action has long been a focal interest

1 of economic and organizational sociology. When information circulates and refreshes in networks, cumulative advantage accrues to entrepreneurs through access to knowledge spillover and through innovation, leading to agglomerative growth and higher organizational performance (Owen-Smith and Powell 2004; Vedres and Stark 2010; Nee and Opper 2012). Whereas close-knit networks foster trust and cooperation (Coleman 1988; Ruef 2010), occupying "structural holes" between otherwise unconnected actors and groups can empower entrepreneurs by unlocking new opportunities (Burt 1992). To deepen an understanding of the

Citation: Nee, Victor, Lisha Liu, and Daniel DellaPosta. 2017. "The Entrepreneur's Network and Firm Performance." Sociological Science 4: 552-579.

Received: July 12, 2017

Accepted: September 5, 2017

Published: October 18, 2017

Editor(s): Jesper Sørensen, Olav Sorenson

DOI: $10.15195 / \mathrm{v} 4 . \mathrm{a} 23$

Copyright: (C) 2017 The Author(s). This open-access article has been published under a Creative Commons Attribution License, which allows unrestricted use, distribution and reproduction, in any form, as long as the original author and source have been credited. (C) (i) link between network structure and firm performance, we explore a context unlike the institutional environment of firms in the United States and Europe: specifically, the Yangzi River Delta, a manufacturing center of domestic capitalist enterprises in China. The founding chief executive officers (CEOs) of private manufacturing firms in seven Yangzi delta cities provided accounts of the ties they relied on during key events along a timeline that tracked the founding and growth of their business ventures. By examining the ties these entrepreneurs used sequentially, we find a differential relationship between network governance structure and firm performance within a regional ecology of coevolving organizational forms.

China's political elite crafted far-reaching economic reforms in 1978 with the objective of stimulating productivity and economic growth in the state-owned economy. An unintended consequence of economic reform and greater reliance on market forces was the empowerment of entrepreneurs and, with this, an explosive increase in the number of privately owned businesses. Rapid economic growth and entrepreneurial profits drove shifts toward an institutional environment in which a diverse mix of organizational forms competed for market share. 
In the transition economy, diverse organizational forms coexist, adapt, and coevolve in production markets (Nee 1992; Walder 1995; Nee and Cao 1999; Oi 1999; Keister 2000; Xiao and Tsui 2007; Lardy 2014). Using a novel sequential framework to analyze concrete network ties over time, we confirm three distinct clusters of CEO network governance structures: traditional kin-based, hybrid nonkin, and rational capitalist. We show that it is the content of ties that matters crucially for the relationship between networks and firm performance. In close-knit, familyrun firms, structural holes are linked to higher return on assets (ROA) and return on equity (ROE). By contrast, in the network governance of rational capitalism, structural holes and higher firm performance are not connected. By incorporating our sequence-analytic typology into a multivariate analysis of structural holes and firm performance, we demonstrate previously unexplored contingencies regarding the applicability of Burt's (1992) theory of structural holes. Although these contingencies emerge within the study of the institutional context of Chinese entrepreneurship, they are suggestive of directions for future research elsewhere. Indeed, China has recently emerged as a crucial test case for the structural hole theory writ large, suggesting a broader import to our findings (e.g., Xiao and Tsui 2007; Burt and Burzynska 2017).

We frame our approach in the context of the transformative institutional change accompanying the emergence of capitalism in China ("Institutional Change and the Rise of Rational Capitalism" section). In the "Network Structure and Network Content" section, we clarify the distinction between the structure and content of network ties; in the "Data" section, we discuss our data from the Yangzi Delta Survey of Entrepreneurs and Firms; in the sections "Sequence Analysis of Entrepreneurial Networks" and "Multivariate Analysis," we detail our sequence analysis of the entrepreneurs' networks and our multivariate analysis of the interaction between structural holes and network governance structures in shaping firm performance across discrete clusters of entrepreneurs; in the "Results" section, we report our results; in the "Discussion" section, we discuss and critique Burt and Burzynska's (2017) discrepant results; and we offer conclusions about our analysis in the "Conclusion" section.

\section{Institutional Change and the Rise of Rational Capitalism}

In departures from state socialism, multiple pathways of market transition have all led to hybrid forms of politicized capitalism in which the state sets the regulatory framework and remains directly involved in a wide range of economic transactions (Oi 1992; Walder 1996; Nee and Opper 2007, 2010). A defining feature of the politicized forms of capitalism is the persistent overlap of political and economic markets and the lack of a clearly defined boundary between the state and the firm (Lin 1995; Walder 1995, 2003; Parish and Michelson 1996). Institutions and cultural beliefs associated with rational capitalism have been long established in the West (Merton 1940; Meyer and Rowan 1977; Weber [1927] 1981, [1904] 2001; Williamson 1985). But the widespread diffusion of these institutionalized routines and rational myths of the Western world notwithstanding (Meyer 2009), rational capitalism has 
yet to displace a pervasive reliance on state intervention in economic life in former state socialist economies.

Market transition theory explains the emergence of a market society as arising from institutional change linked to a greater reliance on markets in economic life (Nee 1989, 1996). An emergent market economy enables entrepreneurs to manufacture products for exchange in markets as opposed to meeting nonmarket production targets set by government administrators. The theory argues that the replacement of bureaucratic allocation by market mechanisms involves a shift of power to entrepreneurs and direct producers. First, markets provide entrepreneurs and producers with a greater set of choices, enabling them to develop new means and modes for cooperation and exchange outside of state-controlled allocation. Second, marketization releases rewards based on a firm's performance. Lastly, markets endogenously expand opportunities for entrepreneurs to detect and assess new opportunities for profit making.

The transition to a market economy in China enabled and motivated the emergence of markets for innovation and increased reliance on innovative activity by firms to gain competitive advantage in markets (Nee, Kang, and Opper 2010). Manufacturing firms competed for innovations to upgrade production processes and existing product lines with novel industrial designs, adopt new management techniques, and license or develop new patents.

Not surprisingly, given the Yangzi River Delta's long history as a robust commercial center, a private enterprise economy rapidly developed "from the bottom up" in this region, along with the privatization of state-owned and collective enterprises. Networks and norms furnished the social cement for dynamically evolving informal and formal economic institutions (Nee and Opper 2012). In the private enterprise economy, traditional, hybrid, and modern corporate forms of rational capitalism coexist in a regional ecology of organizational forms.

\section{Traditional}

Historically, merchant households and family-owned craft workshops flourished in urban centers in the Yangzi River Delta region. In the traditional form of merchant capitalism, patrimonial authority was the organizing principle of family businesses (Weber [1922] 1978). Kinship ties provided the basis for trust and cooperation (Hamilton and Kao 1990). Today, private firms in the Yangzi River Delta region are listed predominantly as limited liability companies (LLCs), but the majority of these companies are owned by the firms' founders and, especially in the formative years, were organized as family businesses.

\section{Hybrid}

Hybrid organizational forms emerged in response to pressures for state-owned and collective enterprises to adapt to market forces and competition (Nee 1992; Oi 1992; Walder 1996). In time, and despite state-crafted efforts to implement economic reforms, state-owned and collective enterprises were massively loss making under competitive pressure from private firms (Lardy 2014). Though many firms were shuttered by local governments, the privatization of local, state-owned firms gained 
momentum in the late 1990s. A common practice in the privatization of loss-making, state-owned firms was for local governments to pass ownership to a factory director in a negotiated transaction, which obligated the new owner to retain the firm's employees. This meant that the new CEO of the privatized firm relied on longstanding personal ties in the founding and development of the business.

Hybrids encompass not only privatized firms but also traditional partnerships reinvented as a means for business partners to start up private firms in more capitaldemanding manufacturing and technology-enabled industrial sectors. As with family businesses, the reinvention of traditional business partnerships relied on strong personal ties for trust and cooperation, but such ties were typically based on nonkin relationships. In an institutional environment where state-owned banks discriminated against private enterprise, partnerships allowed professionals to pool their capital to found start-up firms, often in technology-intensive industrial sectors with higher costs of entry. In both the reinvented partnership and privatized, state-owned firms, founders shared a common reliance on the strength of nonkin personal ties in managing their firms.

\section{Rational Capitalist}

In the modern corporate form, "a formal, rationally organized social structure involves clearly defined patterns of activity in which, ideally, every series of actions is functionally related to the purposes of the organization." (Merton 1940:560). Accordingly, in rational capitalism as it emerged in the West, CEOs of corporations rely on neither kinship nor network closure in managing their firms (Berle and Means 1932; Barnard 1968; Aldrich and Ruef 1999). Rather, they are likely to seek help from alters on the basis of functional role, know-how, and capability.

As part of the state-crafted economic reform, the Company Law enacted in 1994 codified organizational routines and myths of the modern corporation as the basis for the legal form of LLCs and public corporations. Guthrie's (1999) study of state-owned enterprises shows that rational myths codified in the Company Law did in fact guide the reform of state-owned enterprises in Shanghai's industrial and commercial economy, establishing trends in the region. In the next phase of reform, entrepreneurs of private manufacturing firms joined the movement to incorporate under the Company Law. These entrepreneurs followed the listed public corporations in mimicking rational myths and cultural beliefs of modern corporations and defining the role of the $\mathrm{CEO}$ as a corporate leader in order to gain legitimacy for private enterprise. Numerous channels of information expedited the diffusion of rational myths and organizational practices of the modern American corporation. Social learning, legitimacy seeking, and mimicking rational capitalism quickened the process of diffusion of rationalized organizational practices and routines (Nee and Opper 2012; Tsui, Zhang, and Chen 2017).

\section{Network Structure and Network Content}

An underlying trend in market transition-accompanying the expansion of markets for innovation and reliance on innovation by firms-is a parallel shift toward 
openness in entrepreneurs' networks. When describing networks, closure refers to the degree to which key contacts tend to know one another. Within closed networks, which are dense networks of overlapping mutual relations, entrepreneurs can benefit from advice, information, and material assistance by having embedded, strong ties with trusted alters (e.g., Coleman 1988; Uzzi 1996). In contrast, network openness refers to the absence of dense webs of mutual relationships among one's key contacts and the presence of gaps in the network structure.

As Granovetter (1973) argued, social ties that span larger distances in the network space can provide conduits for new and novel information. This is because contacts who mutually belong to the same dense web of relationships will tend to already know the same things, whereas contacts located beyond this closed circle may be privy to new information. Burt's (1992) structural hole theory formalized and extended these insights by arguing that actors who bridge a gap in a network are better positioned to learn about novel ideas and useful information and control the flow of information between the communities they connect (Burt 2004). These brokerage positions are said to be surrounded by structural holes in that there are few (if any) alternative paths between the communities they connect.

Applied to our data, the theory of brokerage predicts a positive association between structural holes in an entrepreneur's network and the performance of the entrepreneur's firm. However, evidence for structural hole positioning and brokerage as social capital is based largely on research involving American and European corporations. It may be that the structural hole theory is contingent on the nature of the institutional and cultural context. For example, Xiao and Tsui (2007) have recently shown that structural holes are not linked with individual success in a sample of Chinese managers in four high-tech firms. They suggest that Burt's theory may not hold in the cultural context of high-commitment organizations, in which boundary-spanning brokers are suspected by others of uncertain loyalties.

In our analysis, we examine not only network structure-measured in terms of the entrepreneur-founder's access to structural holes-but also network content (cf. Podolny and Baron 1997). By network content, we mean the mix of different types of ties appearing in an entrepreneur's network of key contacts. We focus especially on the mix between professional and personal relationships that the entrepreneur relied on at key points in the founding and history of the firm. This focus allows us to introduce a second axis along which networks can be characterized as either open or closed.

Entrepreneurs who build their networks heavily around professional relationships predominantly rely on colleagues (whether inside or outside the firm) for advice, information, and material assistance. A dominance of such professional ties in the entrepreneur's network signals an openness to people outside his or her immediate social orbit and is contingent on functional role and human capital (training, experience, knowledge, and expertise). In contrast, an entrepreneurial network dominated by kin and close personal relations (e.g., classmates and neighbors) is closed in the sense that ties reflect social proximity rather than human capital and specialized knowledge or expertise. In an institutional environment where property rights and legal recourse are unreliable, reliance on kinship and friendship often brings specific benefits of higher trust and solidarity (Peng 2004). Yet in a market 
economy in which innovative activity is important for business success, closed kinship and nonkin networks can seal off access to novel ideas, entrepreneurial opportunities, and useful tacit knowledge that is available to competitors with open networks.

In sum, networks can be more or less open in two distinct ways: (1) by featuring structural holes and thus bearing opportunities for valuable brokerage and recombination and (2) by featuring a predominance of professional ties formed on the basis of human capital rather than kinship or other forms of social proximity. Clearly, these two elements of openness are often correlated in practice. Kin and other strong social ties are less likely to bridge large distances in the network space (Granovetter 1973). Accordingly, structural holes should be less common in networks that are dominated by such ties compared with networks that are dominated by professional and other less personal connections. But when analyzing entrepreneurial networks, it is nonetheless important to distinguish the effect of structural holes per se from that of reliance on professional connections: is it the structural hole itself that matters or, rather, the types of network ties correlated with this structural feature?

\section{Data}

Our data come from the third wave (conducted in 2012) of the Yangzi Delta Survey of Entrepreneurs and Firms, a decadelong longitudinal study of the emergence of modern capitalism in China (2005 to 2017). The study follows 711 entrepreneurs of private manufacturing firms randomly sampled in seven cities: Hangzhou, Ningbo, and Wenzhou (Zhejiang Province); Nanjing, Changzhou, and Nantong (Jiangsu Province); and Shanghai. The economic and geographical diversity of the regional economy and the array of industries sampled (textile, medical and pharmaceutical, ordinary machinery, vehicle and automobile parts, and communication equipment, computer, and electronic manufacturing) contribute to the utility of this data set in a systematic study of the mechanisms in the emergence of a private enterprise economy in China. The sampling frame was stratified by location, industrial sector, and size of the firm. The sample was drawn from complete local firm registers. As a stratified random sample, it oversampled medium (100 to 300 employees) and large (more than 300 employees) industrial firms and limited the inclusion of small firms (10 to 100 employees) to no more than two-thirds of the sample. About 100 firms were drawn from each of the seven cities. For a detailed account of the research design, sampling, and survey methodology, see Nee and Opper (2012:52-70).

The Market Survey Research Institute of the Shanghai Academy of Social Sciences (now a private survey research firm) conducted the survey. Two professional survey researchers participated in face-to-face interviews with the CEOs at the CEOs' factories. If a CEO was not present or was busy, a new appointment was set up by the survey research team. To secure detailed financial data on firm performance, the CEO was invited to ask the firm's chief financial officer to complete the second part of the survey questionnaire on firm size, structure, ownership, performance, competition, taxation, and finance for the three years before the survey. The aim was to build a longitudinal data set. This meant that the survey questionnaire 
used in the surveys that were conducted in 2006 and 2009 was largely unchanged for the 2012 survey apart from a new lab-in-the-field experiment and the addition of a network name-generator module used for the General Social Survey, which Nee and Opper adapted to the timeline and social context of the emergence of modern capitalism in China.

Among the 700 firms in the 2012 survey, 9 percent were large, 25 percent were medium sized, and 66 percent were small enterprises. The median number of employees among the firms sampled was 67 , and the mean was 133 . The median annual sales of firms in the sample was 8.6 million Chinese yuan (CNY), and the mean was 24.9 million CNY. Eighty-four percent of the entrepreneurs surveyed were male, and 16 percent were female. The median of the entrepreneurs' annual income from the firms was between 200,000 and 250,000 CNY. The median age of the entrepreneurs was 45 years, and the mean was 46 years. The median education level of the entrepreneurs was junior college (attained by 31 percent). Fifty-four percent of the entrepreneurs held rural household registration at birth. Twenty-five percent were members of the Communist Party of China (CPC), and 5 percent previously held a cadre position in a government office. Eighty percent of those in our sample were founders of their firms, and 88 percent were owners (sometimes along with others). Thirty percent of the firms had been privatized; they had previously existed as state-owned and collective enterprises before registering as private firms. Reflecting the high retention rate, 75 percent of the respondents in the 2009 survey participated in the 2012 survey of entrepreneurs and firms.

\section{Sequence Analysis of Entrepreneurial Networks}

To identify discrete network governance types in the data, we rely on the entrepreneurs' accounts of the network contacts they relied upon at different stages in the life courses of their firms. Our goal is twofold. First, we want to differentiate each firm by its CEO's network governance structure. Second, we want to capture change over time both within and across network governance types in order to assess the proposition that market transition leads to convergence in firms' reliance on increasingly human capital-based governance.

The sequence of key network contacts in a firm's history is based on responses to six name-generator questions. The first asks the respondent to report the network alter who was most valuable to him or her in founding the firm. The subsequent five questions ask, in turn, who was most valuable at the time of one of five postfounding events that were significant in the firm's history (based on reports from the respondent). In each case, respondents could report a new alter or one of the same alters named previously. Respondents further assigned roles to each alter based on the following set: nuclear family, other relative, neighbor, CPC member, childhood tie, classmate, military tie, workplace colleague, business association member, or none of the above. By examining individual descriptions of alters coded as "none of the above," we determined that this residual category often involved nonworkplace professional ties (e.g., a professional contact in a different firm). One clear benefit of this novel, event-based network instrument is that the explicit connection between each alter and one or more specific events in the history of the 
firm likely improves a respondent's accuracy in recalling and characterizing these relationships (Sorenson 2017).

Using the responses to these name-generator questions, we induced a sixelement sequence for each entrepreneur. The six significant events in the life course of the firm (including the founding event) are ranked in chronological order, and the element assigned to each sequence position reflects the type of alter whom the entrepreneur relied upon during that event. After an exploratory analysis in which all 10 roles were treated separately, we collapsed them into four exclusive categories: (1) kin-based ties (family or relative), (2) nonkin personal ties (neighbor, party, childhood, classmate, or military), (3) workplace ties (colleague), and (4) nonworkplace professional ties (business association or other). ${ }^{1}$ We also examined sequences in which ties are categorized by both role and duration. However, duration did not substantively affect the clustering solutions produced by the sequence analysis, so we opted for the more parsimonious element set. Finally, we dropped 25 respondents who provided missing or incomplete sequence data, leaving us with complete six-element network sequences for 675 entrepreneurs.

We applied an optimal matching algorithm (Abbott and Tsay 2000) to entrepreneurs' network sequences to identify clusters of firms with similar network trajectories. The procedure is as follows: Every unique sequence observed in the data is compared with every other, producing a matrix of pairwise dissimilarities. We observed a total of 260 unique sequences in the data, which means that the number of pairwise comparisons exceeded $33,000 .^{2}$ The dissimilarity between two sequences $i$ and $j$ reflects the "cost" of turning one into the other by using a combination of "indels" (insertions or deletions) and "substitutions." Indels make two sequences more similar by inserting or deleting elements, whereas substitutions replace one element with another. For example, consider two five-element sequences made up of letters in the alphabet: AABADF and CAABAD. By using only indels, the second sequence could be turned into the first by deleting $C$ and inserting an $F$ at the end. If the two sequences were AABADF and AACADG, we could turn the second into the first through substitution by changing $C$ to $B$ and $G$ to $F$.

As the name suggests, the optimal matching procedure turns one sequence into another by using the optimal (i.e., minimal cost) combination of indels and substitutions. Thus, the key modeling decisions concern the relative costs of these different moves. Following common practice, we assigned substitution costs based on observed transition probabilities. Specifically, the cost of substituting element $i$ for element $j$ reflects the mean of the directed transition probabilities between $i$ and $j$ such that substituting elements that rarely neighbor one another in observed sequences is more costly than substituting two elements that often neighbor one another. ${ }^{3}$ We set the cost of indels at 2 , which equals the maximum possible substitution cost. ${ }^{4}$ The ultimate goal of the optimal matching procedure is to identify a data-driven typology for further analysis. Once the sequence dissimilarity matrix has been obtained, the typology is derived by using the pairwise dissimilarities to group the observed sequences into a manageable number of clusters. Following standard procedures, we employed an agglomerative hierarchical clustering algorithm based on Ward's linkage criterion to produce three distinct clusters. Rather than relying on a priori assumptions concerning the desired number of clusters, the 


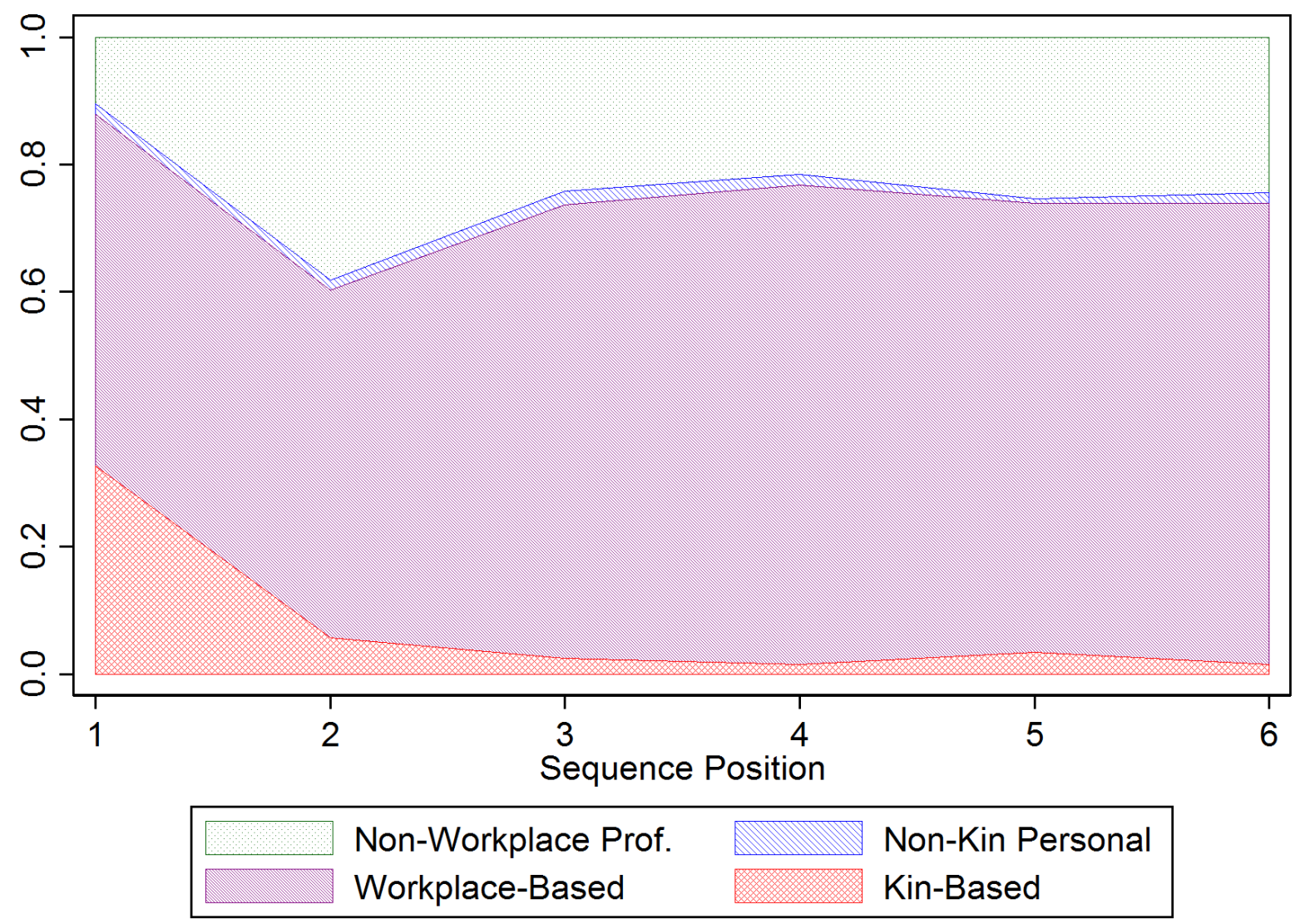

Figure 1: Network sequence trajectories of rational capitalist firms. The types of ties relied upon during chronologically ordered key events are distinguished by color (see legend). The $y$ axis displays cumulative density.

three-cluster solution is based on an empirical stopping rule (Duda, Hart, and Stork 2001).

The three clusters map closely onto the network governance structures previously described. Figures 1, 2, and 3 track the relative prevalence of the different types of network ties at different life course stages for the firms in each cluster (Cornwell 2015). Figure 1 shows that entrepreneurs in the first and largest cluster $(N=379)$ relied heavily on ties with professional colleagues at all observed stages. These are the rational capitalist firms that have relied consistently on human capital-intensive governance structures. Figure 2 shows that entrepreneurs in the second cluster $(N=163)$ relied heavily on kin-based ties for early events in their firm's life course before gradually shifting toward workplace-based ties in later stages. These are the traditional kin-based firms. Congruently, Figure 3 shows that entrepreneurs in the third cluster $(N=133)$ typically relied on nonkin personal ties for aid with early events in their firm's life course before increasingly drawing 


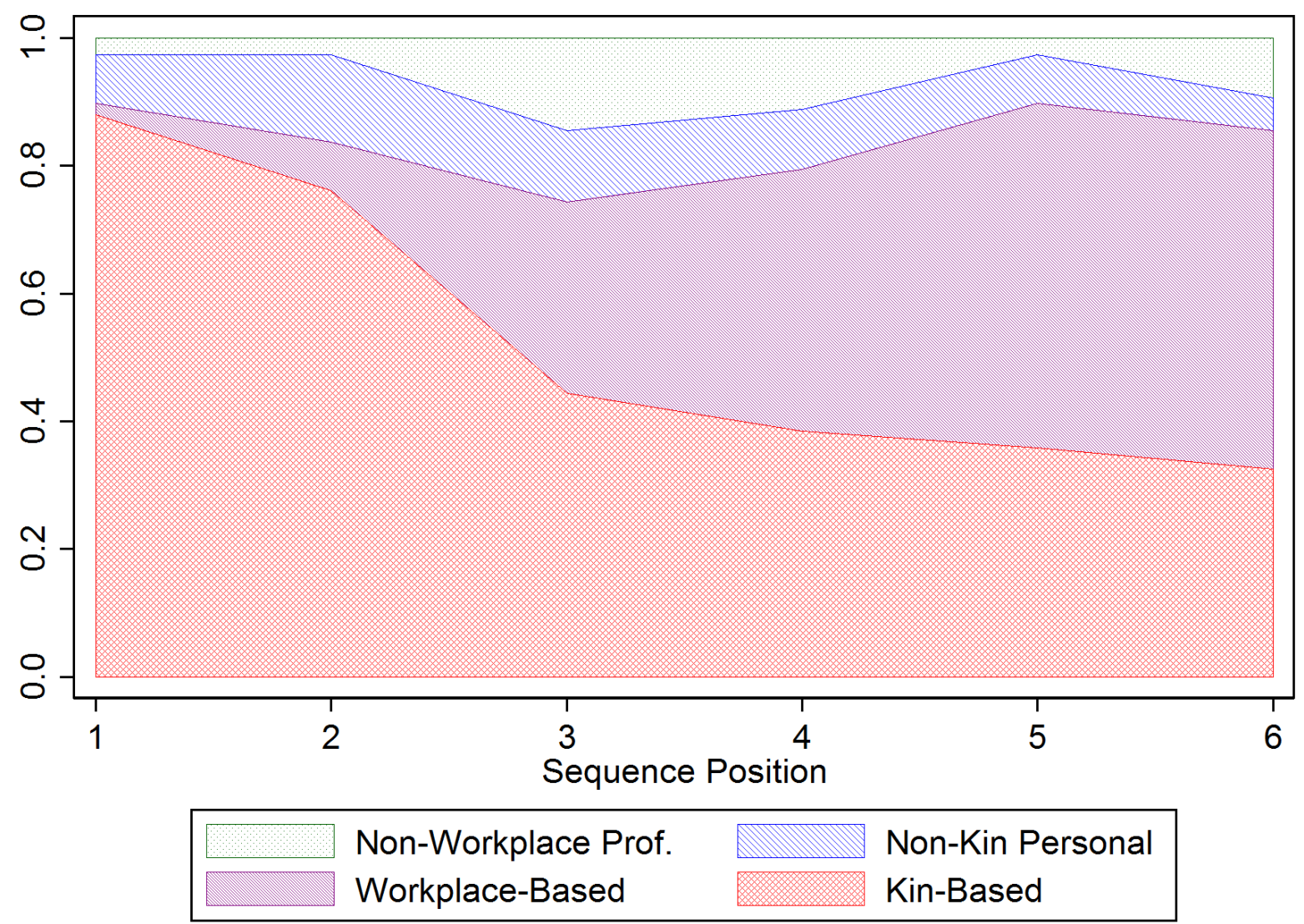

Figure 2: Network sequence trajectories of traditional kin-based firms. The types of ties relied upon during chronologically ordered key events are distinguished by color (see legend). The $y$ axis displays cumulative density. 


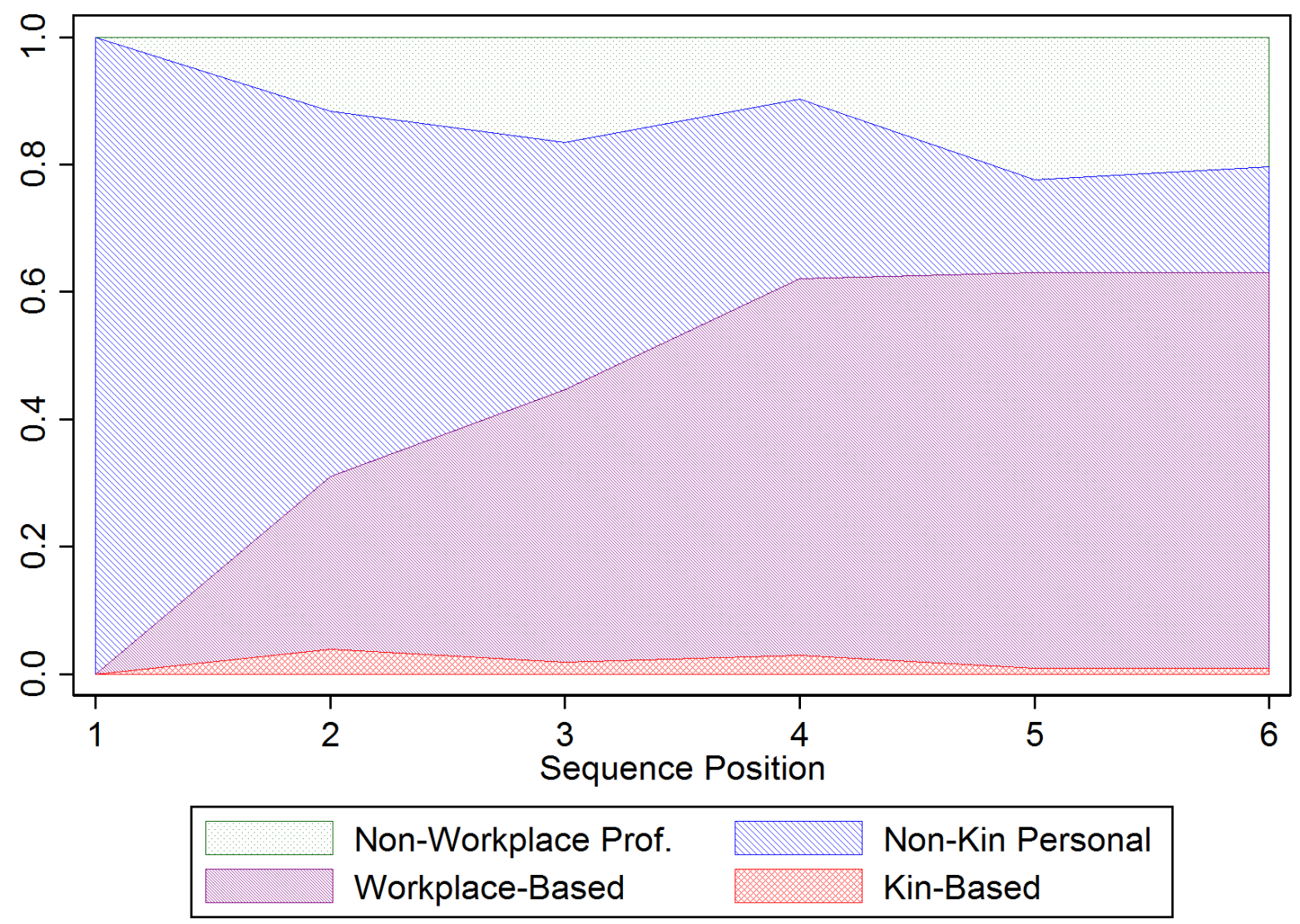

Figure 3: Network sequence trajectories of hybrid nonkin firms. The types of ties relied upon during chronologically ordered key events are distinguished by color (see legend). The $y$ axis displays cumulative density.

clusters increasingly rely on professional ties rather than kin or nonkin social capital in later stages of a firm's development. In part, this reflects the well-known shift to reliance on professional managers by founders of family firms as their businesses mature (Berle and Means 1932).

\section{Multivariate Analysis}

We next present a multivariate analysis of firm performance as a function of network governance, with openness measured in terms of both the structure and content of ties. For firm performance, we employed two standard measures: ROA and ROE. ${ }^{5}$

For network governance structure, we simply use dummy variables indicating each firm's membership in one of the three clusters: traditional kin-based firms, hybrid nonkin firms, and modern corporate firms. As a measure of structural openness, we use network constraint: the extent to which an individual's network time and energy are absorbed in ties with one contact or group of contacts as opposed to being more evenly dispersed (Burt 1992). Network contacts were 
elicited through the six event-based name generators discussed in the previous section as well as additional questions regarding the (up to four) people who were most valuable to a firm's business activities during the present year, the one person who has been the most difficult to deal with during the present year, and the most valuable senior employee during the present year.

In contrast to the sequence analysis, in which we focused on change over time in key contacts, our measurement of network constraint focuses only on the static network elicited by aggregating all of the entrepreneur's named contacts. This is because respondents were not asked how long a given alter has known any other alter or how one alter was connected to other alters at different points in the past. The inclusion of such questions would have exponentially increased the length of the network questionnaire and would have raised concerns about response accuracy. Although the timeline position of each ego-alter relationship allows us some longitudinal perspective, we are unable to measure network constraint longitudinally. ${ }^{6}$

High network constraint indicates the absence of structural holes in an actor's network and therefore fewer opportunities for valuable brokerage. Thus, constraint decreases with the size of a person's network and increases with the density or closure among his or her contacts as well as the extent to which one contact is strongly connected with a person's other contacts. Following Burt (1992), we measure the extent to which each network alter $j$ constraints ego $i$ as

$$
c_{i j}=\left(p_{i j}+\sum_{q} p_{i q} p_{q j}\right)^{2}, q \neq i, j
$$

where $p_{i j}$ measures the proportion of $i$ 's contacts directly invested in alter $j$ and $\sum_{q} p_{i q} p_{q j}$ measures the proportion of $i$ 's contacts indirectly invested in $j$ through other alters $q$ who are also tied to $j$. To calculate these relevant proportions, we weighted all contacts (between $i$ and $j$ and between $j$ and $q$ ) according to $i$ 's classification of the relationship as distant (1), close (2), or neither (0). ${ }^{7}$ Network constraint $C_{i}$ for each entrepreneur is the summed total $\sum_{j} c_{i j}$.

We also included a set of control variables that could potentially confound the relationships between firm performance and the network-based explanatory variables.

\section{CEO's Personal Characteristics}

The CEO's household registration at birth (rural $=1$ ) could influence his or her access to interpersonal connections and network formation given China's enormous rural-urban divide. Gender $($ male $=1)$ is potentially correlated with both network and firm characteristics in a male-dominated business environment. We also include dummy variables for CPC membership (party member $=1$ ) and whether the CEO ever held a cadre position in government office (yes $=1$ ) because both may affect a person's political connections, which represent one category of nonkin personal ties. 


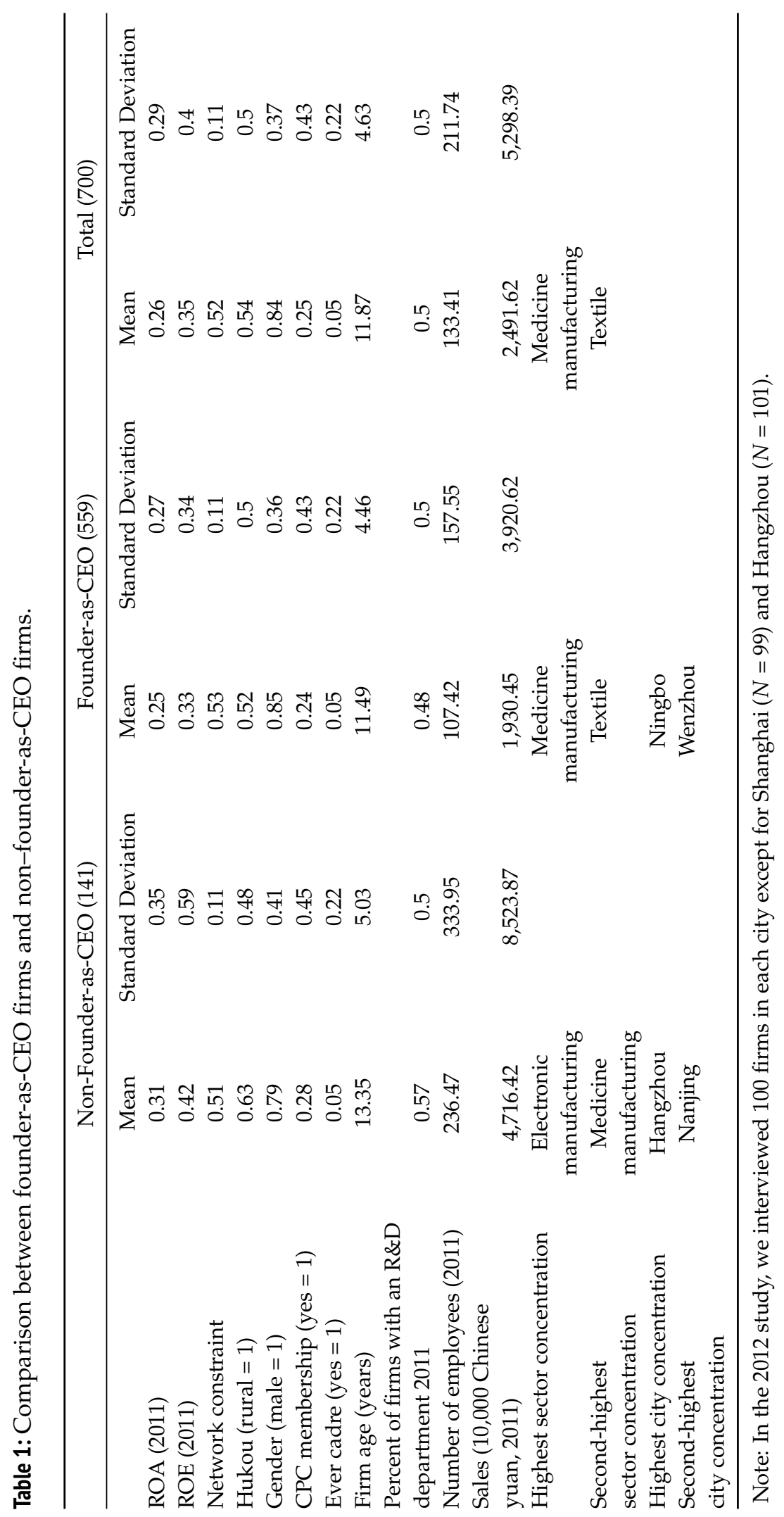




\section{Firm Characteristics}

We included a dummy variable for whether a firm has a research and development (R\&D) department (yes $=1$ ), which might facilitate innovative activities and correlate positively with firm performance. We also included firm age as a covariate because the CEO's network develops over the firm's history, and firm performance may be correlated with firm age. Finally, we included fixed effects for industrial sector and city in order to ensure appropriate comparisons across firms. ${ }^{8}$

We restricted our analysis to the 559 firms for which we knew that the CEO was also a founder of the firm. We think that it is crucial to focus on founder-as-CEO firms (which account for 80 percent of our sample) when analyzing network effects on performance.

The role of a CEO tends to be different in the founder-as-CEO and non-founderas-CEO firms. The entrepreneurial function when founding a firm consists of devising new combinations of resources, organizing production, marketing, and creating novel products (Schumpeter 1942). In founder-as-CEO firms, the CEO is the single most important person in the firm, and his or her agency is well reflected in organizational decision-making. The status of the current CEO as a founder of the firm has been shown to reflect the power of the CEO within the firm (Adams, Almeida, and Ferreira 2005) as the individual who is ultimately responsible for firm processes and outcomes (Finkelstein 1992) and who determines the success of the firm (Daily and Johnson 1997). Given the role played by a CEO as the founder of a firm, the network contacts of founder-CEOs are likely to have influence on crucial decisions made in the firms. By contrast, the power and influence of a professional manager-CEO is restricted because of the existence of large shareholders behind him or her. Therefore, our focus on founder-as-CEO firms helps to justify the focus on network governance as the channel through which the CEO's network affects firm performance.

Table 1 shows descriptive statistics for both founder-as-CEO firms and nonfounder-as-CEO firms. Table 2 displays descriptive statistics across the three network governance clusters for founder-as-CEO firms. The three clusters are similar with regard to most dimensions, which likely reflects the convergence we observed in the sequence analysis. However, there are some notable differences. Namely, rational capitalist firms tend to have more patents than traditional family firms, and hybrid nonkin firms tend to be older and have more employees than rational capitalist firms.

To capture the contingent ways in which network structure and network content are associated with higher or lower performance, we employed a set of nested ordinary least squares regression models that examine the association between network constraint and firm performance both in the aggregate and separately by network governance type.

\section{Results}

Table 3 summarizes results from our regression models predicting firm performance as a function of network constraint and governance structure with the previously 


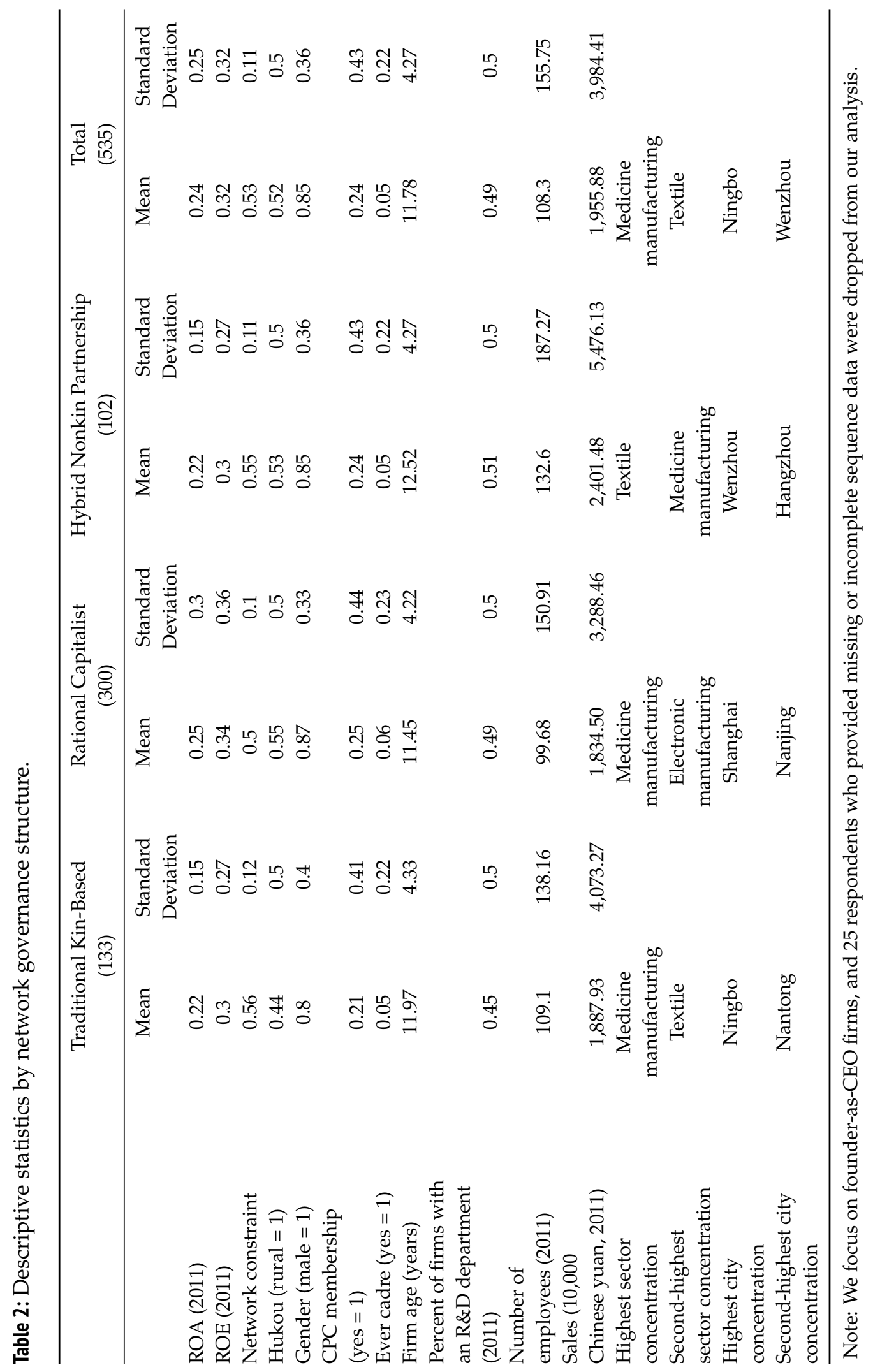


Table 3: Network constraint and firm performance.

\begin{tabular}{|c|c|c|c|c|}
\hline & \multicolumn{2}{|c|}{ ROA (2011) } & \multicolumn{2}{|c|}{ ROE (2011) } \\
\hline & Model 1 & Model 2 & Model 3 & Model 4 \\
\hline Network constraint & $\begin{array}{c}-0.124 \\
(0.058)\end{array}$ & $\begin{array}{c}-0.275 \\
(0.105)\end{array}$ & $\begin{array}{c}-0.155 \\
(0.137)\end{array}$ & $\begin{array}{c}-0.421 \\
(0.210)\end{array}$ \\
\hline Hukou (rural = 1) & $\begin{array}{c}0.013 \\
(0.019)\end{array}$ & $\begin{array}{c}0.012 \\
(0.018)\end{array}$ & $\begin{array}{c}0.013 \\
(0.031)\end{array}$ & $\begin{array}{c}0.011 \\
(0.030)\end{array}$ \\
\hline Gender $($ male $=1)$ & $\begin{array}{c}0.021 \\
(0.029)\end{array}$ & $\begin{array}{c}0.021 \\
(0.029)\end{array}$ & $\begin{array}{c}0.023 \\
(0.035)\end{array}$ & $\begin{array}{c}0.022 \\
(0.035)\end{array}$ \\
\hline CPC membership (yes $=1$ ) & $\begin{array}{c}-0.015 \\
(0.013)\end{array}$ & $\begin{array}{r}-0.017 \\
(0.013)\end{array}$ & $\begin{array}{c}-0.016 \\
(0.022)\end{array}$ & $\begin{array}{r}-0.018 \\
(0.024)\end{array}$ \\
\hline Ever cadre $($ yes $=1)$ & $\begin{array}{c}0.092 \\
(0.107)\end{array}$ & $\begin{array}{c}0.093 \\
(0.107)\end{array}$ & $\begin{array}{c}0.088 \\
(0.152)\end{array}$ & $\begin{array}{c}0.090 \\
(0.153)\end{array}$ \\
\hline Firm age & $\begin{array}{c}-0.008 \\
(0.004)\end{array}$ & $\begin{array}{c}-0.008 \\
(0.004)\end{array}$ & $\begin{array}{c}-0.008 \\
(0.006)\end{array}$ & $\begin{array}{c}-0.008 \\
(0.006)\end{array}$ \\
\hline Has an R\&D department (yes $=1$ ) & $\begin{array}{c}0.017 \\
(0.009)\end{array}$ & $\begin{array}{c}0.018 \\
(0.009)\end{array}$ & $\begin{array}{c}-0.003 \\
(0.021)\end{array}$ & $\begin{array}{c}-0.001 \\
(0.020)\end{array}$ \\
\hline \multicolumn{5}{|l|}{$\begin{array}{l}\text { Network governance } \\
\text { (kin-based = reference) }\end{array}$} \\
\hline Rational capitalist & $\begin{array}{c}0.005 \\
(0.024)\end{array}$ & $\begin{array}{c}-0.112 \\
(0.051)\end{array}$ & $\begin{array}{c}-0.013 \\
(0.043)\end{array}$ & $\begin{array}{r}-0.245 \\
(0.100)\end{array}$ \\
\hline Hybrid nonkin & $\begin{array}{c}-0.004 \\
(0.019)\end{array}$ & $\begin{array}{r}-0.140 \\
(0.126)\end{array}$ & $\begin{array}{r}-0.009 \\
(0.039)\end{array}$ & $\begin{array}{r}-0.180 \\
(0.167)\end{array}$ \\
\hline \multicolumn{5}{|l|}{ Interactions } \\
\hline $\begin{array}{l}\text { Rational capitalist } x \\
\text { network constraint }\end{array}$ & & $\begin{array}{c}0.216 \\
(0.106)\end{array}$ & & $\begin{array}{c}0.433 \\
(0.171)\end{array}$ \\
\hline $\begin{array}{l}\text { Hybrid nonkin } \mathrm{x} \\
\text { network constraint }\end{array}$ & & $\begin{array}{c}0.244 \\
(0.217)\end{array}$ & & $\begin{array}{c}0.306 \\
(0.294)\end{array}$ \\
\hline Intercept & $\begin{array}{c}0.403 \\
(0.069)\end{array}$ & $\begin{array}{c}0.490 \\
(0.081)\end{array}$ & $\begin{array}{c}0.569 \\
(0.128)\end{array}$ & $\begin{array}{c}0.721 \\
(0.173)\end{array}$ \\
\hline$R^{2}$ & 0.087 & 0.089 & 0.084 & 0.087 \\
\hline
\end{tabular}

Note: $N=535$. Robust standard errors (clustered by city) are in parentheses. Industrial sectors and cities are controlled with fixed effects.

discussed control variables. All models include robust standard errors clustered by city. As a baseline, model 1 shows a negative association between network constraint and ROA; model 3 shows a less precise but still negative association for ROE. This suggests a likely baseline association between network constraint and firm performance, adjusting for membership in one of the three network governance clusters and a robust set of controls. ${ }^{9}$ However, models 2 and 4 incorporate interaction terms between cluster membership and network constraint in order to separately estimate the network-firm performance association for firms with different network governance structures, and this second set of models suggests that the association between network constraint and firm performance depends 


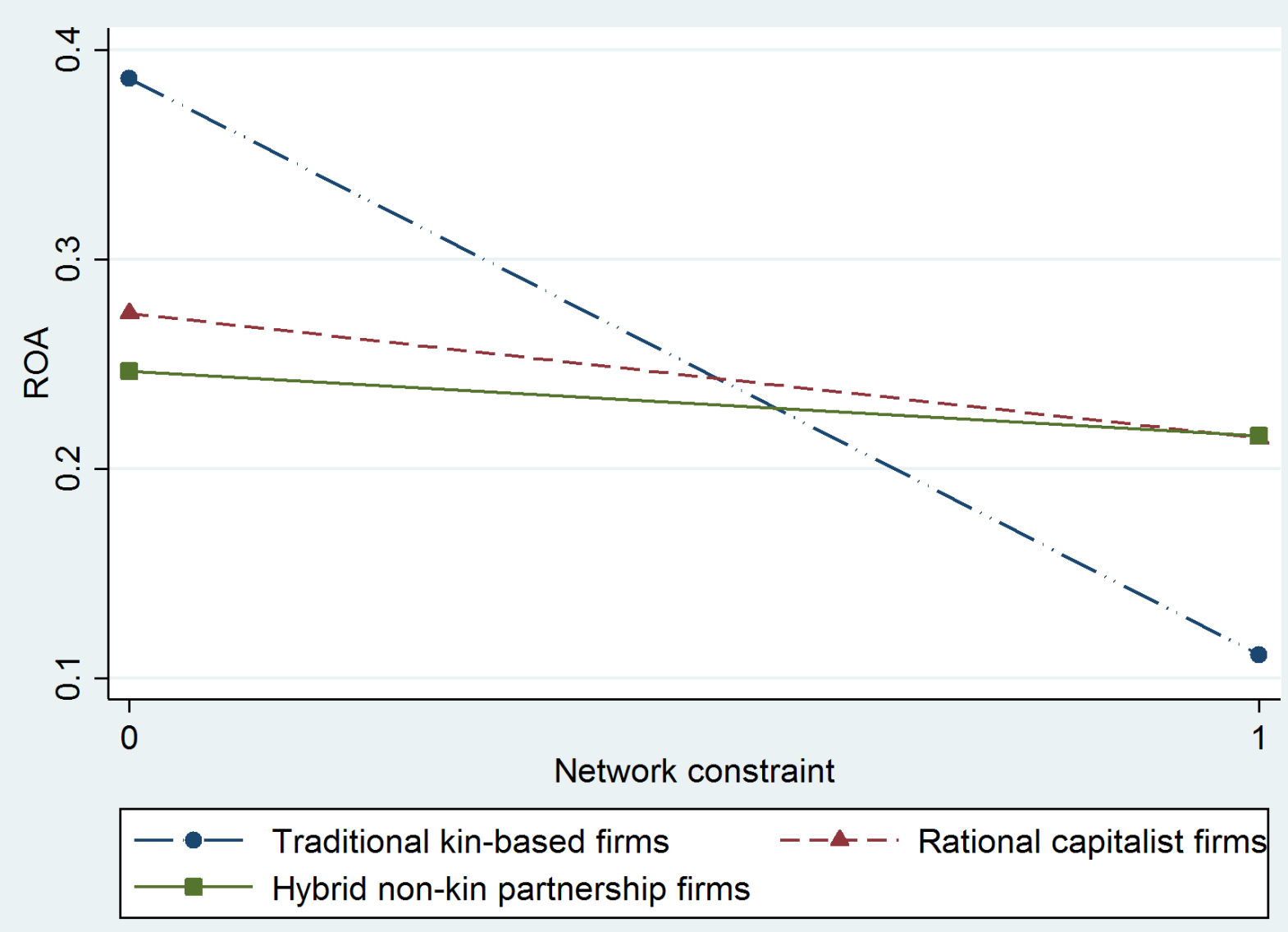

Figure 4: ROA and network constraint by CEO network governance structure. The plot shows the marginal association between network constraint and ROA by network governance structure (based on model 2 in Table 3). 


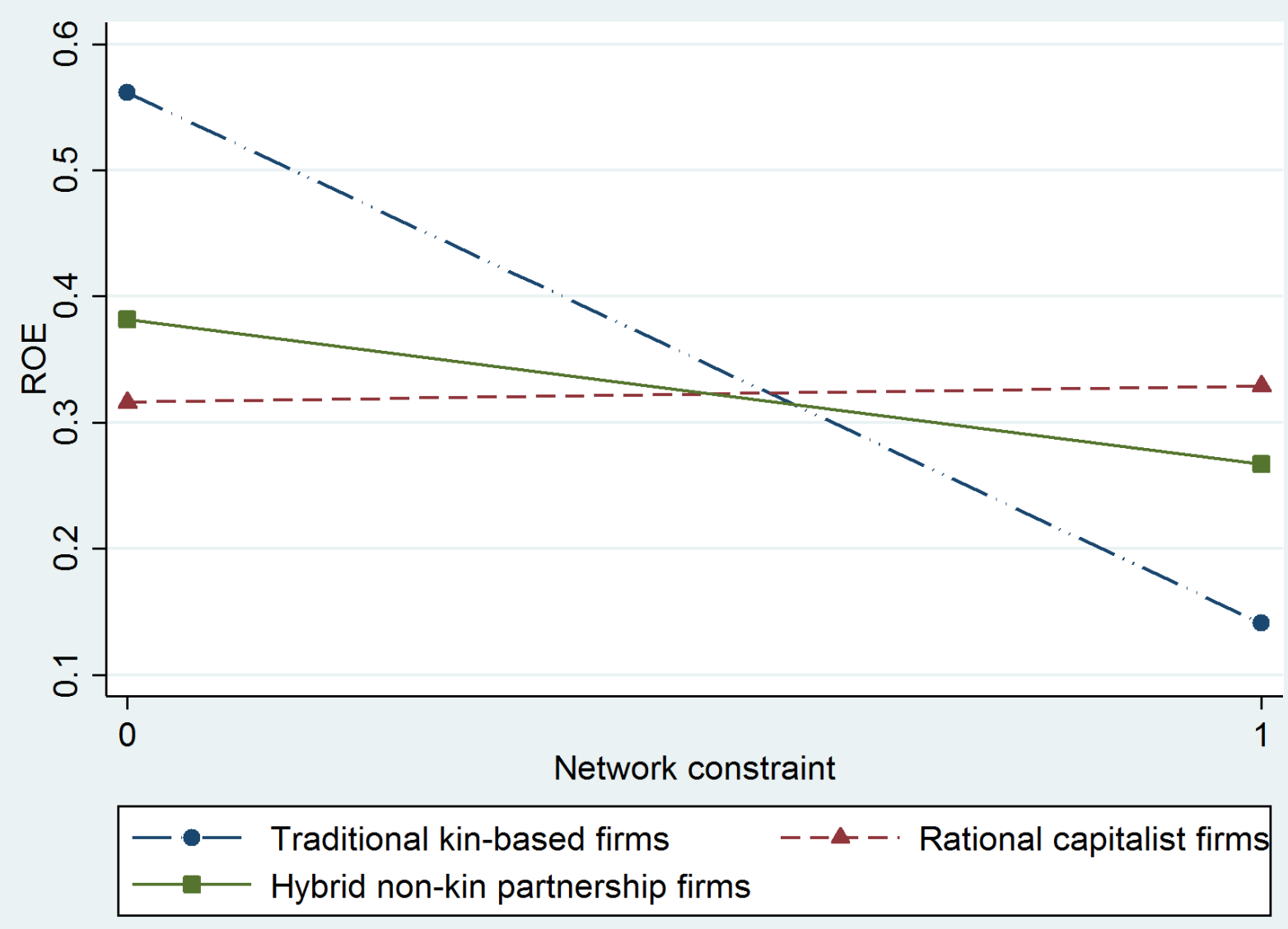

Figure 5: ROE and network constraint by CEO network governance structure. The plot shows the marginal association between network constraint and ROE by network governance structure (based on model 4 in Table 3).

beyond the entrepreneur's closed network becomes especially crucial in bringing higher marginal returns to the firm. As innovative activity increases in importance in China's market economy, entrepreneurs in kin-based firms reach out through bridge ties for new ideas and innovation. For the hybrid nonkin and human capitalbased firms, in contrast, reliance on nonkin ties may already provide exposure to innovative activity inside and outside a firm and thus be a sufficient stimulant to firm performance without the need to maintain structurally diverse or open networks. ${ }^{10}$

\section{Discussion}

Notably, our results differ from those reported by Burt and Burzynska (2017), who also use data from Nee and Opper's 2012 Yangzi Delta Survey of Entrepreneurs and Firms. We focus above on our own, original analysis, but we have also replicated their analyses using the same covariates and show that log network constraint 
(which is inversely correlated with structural holes) negatively predicts a firm's number of employees, annual sales, and number of patents. They argue that their results confirm a positive effect of network openness on business success: "Our first conclusion is that access to structural holes is a competitive advantage in China as in the West" (Burt and Burzynska 2017:238). However, their use of the number of employees, total sales, and patents as outcome measures of business success is highly problematic. These variables reflect accretion over an extended period of time, and they are more related to firm size than firm performance. As such, they introduce a strong potential for reverse causality: Does access to structural holes provide entrepreneurs with opportunities to expand the size of the firm, or do CEOs of larger firms merely have access to larger, more diverse, and more open networks?

Firm size is certainly not a straightforward measure of business success (Goerzen 2007). Indeed, firm size is often used as a control variable in studies that try to measure firm performance more directly (Murphy, Trailer, and Hill 1996). The number of employees on a firm's payroll is a particularly unreliable way to measure firm performance and success. State-owned enterprises tend to have more employees than needed as a means to promote full employment. Many of the larger firms in the sample were privatized firms that were previously owned by the state before being passed on to private owners along with the responsibility of keeping the employees. ${ }^{11}$ In the 2012 survey, the average number of employees in privatized firms was 190 compared with 109 in businesses that were founded at the outset as private firms. Nee and Opper (2012) show that despite their initial advantage in size and asset endowment, these privatized state-owned firms lag in performance over time compared with firms founded at the outset as private businesses-largely because of the obligation to retain the original workers. In other words, lower firm performance characterized privatized firms with more employees rather than firms with fewer employees founded as private businesses at the start-up stage.

To the extent that Burt and Burzynska's (2017) analysis picks up the unmeasured effects of redundant employees, the link between CEO network structure and firm size might reflect a variety of possible mechanisms having little to do with the competitive advantages of open networks. Notably, they find that structural holes are not associated with business success when they restrict their analysis to the CEO's current network by excluding ties relied upon only in the past (see their Table 3). They explain this finding by claiming that limiting an entrepreneur's network to current contacts significantly underestimates the network association with business success because it ignores the important possibility that past contacts "gone into remission can be reanimated to advantage" (p. 232; also see Granovetter [1973]). In other words, they argue that including both past and current contacts is essential to uncovering network advantage. An alternative and arguably more plausible explanation is that the CEO's current network ties do not predict their key outcome variables because those measures do not reflect present-day firm performance. For instance, the firm's number of employees is accrued over many years and through many intertwining causal pathways-some are potentially related to network structure, but many likely are not. Their hypothesis arguing that access to structural holes provides entrepreneurs with a competitive advantage cannot 
be tested by using the number of employees, sales, and patents as measures of business success.

For reasons discussed earlier, we think it is crucial to focus on founder-as-CEO firms when analyzing network effects on performance and innovation. Therefore, unlike Burt and Burzynska, we restricted our own analysis to those 559 firms (80 percent of the overall sample). As an additional test of their hypothesis, we further replicated their analysis using the same controls they used but with the sample restricted to founder-as-CEO firms and with standard measures of firm performance. Table 4 shows the results. The association between log network constraint and present-day firm performance measured in terms of ROA and ROE is negligible.Thus, Burt and Burzynska's (2017:Table 1) findings are not supported when standard measures of firm performance (ROA and ROE) replace firm size. ${ }^{12}$

\section{Conclusion}

In homage to Weber's "iron cage" image, DiMaggio and Powell (1983:147) observed that the "bureaucratization of the corporation and the state have been achieved." They detailed a research program exploring the isomorphism of institutionalized rules and routines in the context of stable organizational fields (Powell and DiMaggio 1991). Following suit, network analysts explored the workings of social structure in markets and organizations also in a framework of comparative statics in equilibrium (Granovetter 1973; Coleman 1988; Burt 1992). In extending the structural hole theory, empirical studies have focused on the networks of managers and individual outcomes, such as pay and promotion, within large firms (e.g., Burt 2004; Kleinbaum 2012). Yet in studies of departures from state socialism, the assumption of equilibrium and comparative statics has been on wobbly grounds. In all the transition economies, there have been pervasive uncertainties and risks associated with institutional frameworks in flux and disequilibrium. To what degree can analytic approaches, which assume conditions of stable equilibrium, be aptly extended to the social and organizational dynamics of transformative institutional change? ${ }^{13}$

The aim of state-crafted economic reform was the renewal of productivity and the growth of a centrally planned economy, but its unintended consequence was a punctuated equilibrium giving rise to self-reinforcing organizational dynamics of decline, the adaptive change of state-owned enterprises, and an explosive birth of privately owned firms. In China's market transition, traditional, hybrid, and corporate organizational forms adapted and coevolved in institutional environments that were undergoing rapid, transformative change. Clearly, the challenge is to analyze the social dynamics of adaptation and the coevolution of this diverse mixture of firms. For economic and organizational sociology, this calls for a regional ecology approach that enables a simultaneous time series analysis of coexisting network structures and organizational forms.

Our study has focused on a large sample of private manufacturing firms in the Yangzi River Delta region. We use the concept of network governance structure to distinguish three broad types of firms: traditional kin-based, hybrid nonkin, and rational capitalist. We confirmed this typology through a sequence analysis of the types of network contacts on whom the sampled CEOs relied at successive key 
Table 4: Adapting Burt and Burzynska's model using ROA and ROE and adjusted sample.

\begin{tabular}{|c|c|c|}
\hline & ROA (2011) & ROE (2011) \\
\hline Log (network constraint $x$ 100) & $\begin{array}{r}-0.075 \\
(0.055)\end{array}$ & $\begin{array}{r}-0.084 \\
(0.069)\end{array}$ \\
\hline Firm age & $\begin{array}{c}-0.014 \\
(0.003)\end{array}$ & $\begin{array}{r}-0.014 \\
(0.003)\end{array}$ \\
\hline Has R\&D department & $\begin{array}{c}0.024 \\
(0.023)\end{array}$ & $\begin{array}{c}0.004 \\
(0.029)\end{array}$ \\
\hline Medicine manufacturing & $\begin{array}{l}-0.008 \\
(0.031)\end{array}$ & $\begin{array}{r}-0.003 \\
(0.039)\end{array}$ \\
\hline Mechanical manufacturing & $\begin{array}{c}0.044 \\
(0.038)\end{array}$ & $\begin{array}{c}0.063 \\
(0.047)\end{array}$ \\
\hline $\begin{array}{l}\text { Transportation equipment } \\
\text { manufacturing }\end{array}$ & $\begin{array}{c}0.072 \\
(0.043)\end{array}$ & $\begin{array}{c}0.127 \\
(0.054)\end{array}$ \\
\hline Electronic manufacturing & $\begin{array}{r}-0.000 \\
(0.033)\end{array}$ & $\begin{array}{c}0.053 \\
(0.041)\end{array}$ \\
\hline Intercept & $\begin{array}{c}0.677 \\
(0.222)\end{array}$ & $\begin{array}{c}0.793 \\
(0.279)\end{array}$ \\
\hline$R^{2}$ & 0.058 & 0.049 \\
\hline
\end{tabular}

Note: $N=559$. Unstandardized coefficients are presented with standard errors in parentheses.

events in their firm's history. Despite the clear differences across the three clusters, especially at early stages of the life course of each firm, our analysis also shows evidence of convergence toward increased openness in entrepreneurs' networks-a clear trend toward increasing reliance on professional colleagues across all three types of firms.

Our multivariate regression analysis shows that the relationship between structural holes in a CEO's network and firm performance depends critically on the firm's network governance structure. Although structural holes are strongly associated with firm performance among traditional kin-based firms, we do not find any such association for hybrid nonkin and rational capitalist firms. The network of CEOs of traditional kin-based firms has the lowest openness among the three network governance structures, and for those firms, reaching beyond the CEO's closed, kin-based network brings higher marginal returns. In our replication of Burt and Burzynska's (2017) analysis, we found that their use of the number of employees, sales, and patents as measures of business success is problematic because these factors are more related to firm size than performance. And we uncovered a problem of reverse causality wherein the link between an entrepreneur's structural holes and business success is likely a feature of larger firms merely having larger and more open networks.

A high-profile challenge to Burt's (1992) structural hole theory comes from Xiao and Tsui (2007), who show that structural holes are not associated with higher career achievement among managers in Chinese high-tech firms. They account for 
this finding by suggesting that the control and informational benefits of structural holes are culturally contingent and fail to materialize in China's collectivistic society, in which the boundary-spanning broker is subject to distrust. Thus, China has emerged as a high-leverage cultural and institutional context for evaluating theories of social capital more generally. Burt and Burzynska's (2017) recent article is in part a response to Xiao and Tsui, purportedly showing that structural holes have the same beneficial effects in the East as in the West.

In this debate, we chart a middle course on the question of the structural hole theory and cultural differences between the East and West. First, Xiao and Tsui's study uses the comparative statics approach to examine within-firm career achievement of middle- and lower-level managers in four Chinese tech firms. But even in this context, the key lies in organizational-level distinctions between high-commitment firms (those emphasizing mutual investment rather than opportunistic brokerage) and low-commitment firms (in which the network correlates of success more closely resemble those attributed to Western organizations). The question of China as a collectivist culture eludes measurement and analysis and remains an omitted variable in the empirical analysis of payoffs to structural holes in Chinese tech firms. Second, the focus on managerial career achievement in two surveys six months apart, although a control for reverse causality, omits the effects of broad shifts in the institutional environment that come with a chronological timeline extending beyond a six-month frame. It is difficult to generalize from Xiao and Tsui's microlevel findings and draw broad inferences about the structural hole theory being applicable in the individualistic West but not in collectivist societies like China. Suppose, for example, that Xiao and Tsui had sampled four family businesses. Might their results then have shown that kin-based managers in these firms with access to structural holes are rewarded for brokering entrepreneurial opportunities for their firm? Thus, although our results are complementary to Xiao and Tsui's in showing no significant effect of structural holes on firm performance in rational capitalist and hybrid nonkin partnership firms in the Yangzi River Delta region, we do not draw the same inference from these findings in light of our regional ecology approach. Furthermore, our sequence analysis of coevolving organizational forms confirms a broad trend toward convergence, pointing to increasing openness in the network structure of CEOs of private firms.

What are the implications of our approach and findings for future research? Clearly, China offers an important "strategic research site" for organizational and economic sociology (Merton [1949] 1968). The 1990s and 2000s witnessed the emergence of organizational forms and economic institutions of modern capitalism in China; however, traditional, hybrid, and rational capitalist forms are still adapting and coevolving. Fukuyama's (1992) "end of history" has not arrived. For this reason, research needs to take into account a regional ecology of firms that coevolve in economic and political markets for profits and survival. Ecologists have long sought to examine organizational behavior in the context of a population ecology of diverse organizational forms (Hannan and Freeman 1989). Our findings show that it is possible to identify empirically discrete network governance structures through sequence analysis of network ties collected on a timeline from a firm's founding through critical events of its development. This, followed by multivariate analysis of 
the association between the entrepreneur's network and firm performance, allows for a deeper understanding of the tension between closure and brokerage posited by the social capital theory.

\section{Notes}

1 Respondents could assign more than one role for particular alters. In such cases, we reduced role combinations to a single role category based on a simple heuristic: Alters are assigned to the role that entails the strongest and most durable ties. Kin-based ties are at the top of this hierarchy and are coded as such regardless of role combinations; next come nonkin personal ties, followed by workplace ties and, finally by nonworkplace professional ties.

2 These pairwise comparisons are conducted by using the standard Needleman-Wunsch algorithm.

3 Formally, the cost of substituting element $i$ for $j$ (or vice versa) equals $2-p(i, j)-p(j, i)$, where $p$ gives a transition probability. Because each directed transition probability varies between 0 and 1, substitution costs vary between 0 and 2 .

4 We have also experimented with higher indel costs (i.e., 2.5) and found substantively similar results.

5 As reported in the 2012 survey (referring to firm performance in 2011).

6 Sorenson (2017) discusses these limitations in detail.

7 Alternatively, we tested models in which ties between two alters reported as "neither close nor distant" were treated as being in-between "distant" and "close" and found nearly identical results. For ties between ego and alter, there are actually four options: "distant," "less close," "close," and "especially close." We coded "distant" and "less close" together as representing a weaker tie (1) and "close" "and "especially close" together as representing a stronger tie (2).

8 We do not include control variables for firm size in our models because our measures of firm performance-ROA and ROE- are relative to firm size. When firm size is included as a control, however, the results are consistent with what we report here.

9 We especially want to highlight the inclusion of fixed effects for cities as localized social, cultural, and economic features that potentially influence the formation of a CEO's network and firm performance.

10 Although we will not devote much attention here to the set of control variables, the effects of firm age and having an R\&D department are worth noting. Younger firms tend to perform better than their older peers, showing the late-mover advantage of firms that entered into a market that had already been developing over time. Having an R\&D department is associated with higher ROA, suggesting returns on innovation.

11 Thirty percent of the firms in the sample were formerly state-owned enterprises. These firms tended to be loss making due in part to the rigidity of the employment policy of local, state-owned enterprises. As Shleifer and Vishny (1994) show, politicians like full employment, and they spend more on wages than an entrepreneur would as a private owner.

12 We identified a coding error that led Burt and Burzynska (2017) to draw erroneous inferences about trust in China in their subsection on network closure and trust. They wondered why "Seventy five percent of event contacts are from a source unknown. The percentage is $93.1 \%$ for nonevent contacts" (p. 238). Yet, they treat workplace ties 
in the network survey as contacts from an unknown source. The "people outside the usual sources for trusted contacts" they refer to are mainly workplace colleagues. Thus, one problem for Burt and Burzynska (2017) may be their relative lack of substantive familiarity with Nee and Opper's research design, data set, and adaptation of the namegenerator module. Readers who are interested in learning more about our replication results of Burt and Burzynska may obtain more detail from the authors.

13 This question is explored in a symposium issue of Rationality and Society (see Calvert 2017; Cameron and Macy 2017; DellaPosta, Nee, and Opper 2017; DiMaggio 2017; Ruef 2017; Solow 2017; van de Rijt 2017).

\section{References}

Abbott, Andrew, and Angela Tsay. 2000. "Sequence Analysis and Optimal Matching Methods in Sociology: Review and Prospect." Sociological Methods and Research 29:3-33. https: //doi.org/10.1177/0049124100029001001

Adams, Renée B., Heitor Almeida, and Daniel Ferreira. 2005. "Powerful CEOs and Their Impact on Corporate Performance." The Review of Financial Studies 18:1403-32. https: //doi.org/10.1093/rfs/hhi030

Aldrich, Howard E., and Martin Ruef. 1999. Organizations Evolving. London, England: Sage. https://doi.org/10.1086/421787

Barnard, Chester J. 1968. The Function of the Executive. Cambridge, MA: Harvard University Press.

Berle, Adolf A. Jr., and Gardiner C. Means. 1932. The Modern Corporation and Private Property. New York, NY: Macmillan.

Burt, Ronald S. 1992. Structural Holes: The Social Structure of Competition. Cambridge, MA: Harvard University Press.

Burt, Ronald S. 2004. "Structural Holes and Good Ideas." American Journal of Sociology 110:349-99. https://doi.org/10.1086/421787

Burt, Ronald S., and Katarzyna Burzynska. 2017. “Chinese Entrepreneurs, Social Networks, and Guanxi." Management and Organization Review 13:221-60. https://doi.org/10. $1017 /$ mor. 2017.6

Calvert, Randall. 2017. "Strategic Rationality and Endogenous Institutional Change." Rationality and Society 29:91-110. https://doi .org/10.1177/1043463116683907

Cameron, Christopher J., and Michael Macy. 2017. “The Local Dynamics of Institutional Change." Rationality and Society. https://doi.org/10.1177/1043463116685663

Coleman, James S. 1988. "Social Capital in the Creation of Human Capital." American Journal of Sociology 94:S95-S120. https ://doi .org/10 . 1086/228943

Cornwell, Benjamin. 2015. Social Sequence Analysis: Methods and Applications. Cambridge, MA: Cambridge University Press. https://doi.org/10.1017/CB09781316212530

Daily, Catherine M., and Jonathan L. Johnson, 1997. "Sources of CEO Power and Firm Financial Performance: A Longitudinal Assessment." Journal of Management 23:97-117. https://doi.org/10.1177/014920639702300201

DellaPosta, Daniel, Victor Nee, and Sonja Opper. 2017. "Endogenous Dynamics of Institutional Change." Rationality and Society 29:5-48. https://doi.org/10.1177/ 1043463116633147 
DiMaggio, Paul. 2017. "Layers of Endogeneity: How Porous Boundaries between State and Society Complicate Institutional Change." Rationality and Society 29:80-90. https : //doi.org/10.1177/1043463116685662

DiMaggio, Paul, and Walter W. Powell. 1983. "The Iron Cage Revisited: Institutional Isomorphism and Collective Rationality in Organizational Fields." American Sociological Review 48:147-60. https : //doi .org/10.2307/2095101

Duda, Richard O., Peter E. Hart, and David G. Stork. 2001. Pattern Classification and Scene Analysis (2 ${ }^{\text {nd }}$ Edition). New York, NY: Wiley.

Finkelstein, Sydney. 1992. "Power in Top Management Teams: Dimensions, Measurement, and Validation." Academy of Management Journal 35:505-38. https://doi .org/10. 2307/ 256485

Fukuyama, Francis. 1992. The End of History and the Last Man. New York, NY: Free Press.

Granovetter, Mark S. 1973. “The Strength of Weak Ties." American Journal of Sociology 78:1360-80. https://doi.org/10.1086/225469

Goerzen, Anthony. 2007. "Alliance Networks and Firm Performance: The Impact of Repeated Partnerships." Strategic Management Journal 28:487-509. https://doi.org/10.1002/smj . 588

Guthrie, Doug. 1999. Dragon in a Three-Piece Suit: The Emergence of Capitalism in China. Princeton, NJ: Princeton University Press.

Hannan, Michael T., and John Freeman. 1989. Organizational Ecology. Cambridge, MA: Harvard University Press.

Hamilton, Gary G., and Kao Cheng-shu. 1990. “The Institutional Foundation of Chinese Business: The Family Firm in Taiwan." Comparative Social Research 12:95-112.

Keister, Lisa. 2000. Chinese Business Groups: The Structure and Impact of Interfirm Relations during Economic Development. Oxford: Oxford University Press.

Kleinbaum, Adam M. 2012. “Organizational Misfits and the Origins of Brokerage in Intrafirm Networks." Administrative Science Quarterly 57:407-52. https://doi.org/10. $1177 / 0001839212461141$

Lardy, Nicholas R. 2014. Markets Over Mao: The Rise of Private Business in China. Washington DC: Institute of International Economics.

Lin, Nan. 1995. “Local Market Socialism: Local Corporatism in Action in Rural China." Theory and Society 24:301-54.

Merton, Robert K. 1940. “Bureaucratic Structure and Personality." Social Forces 17:560-68. https://doi.org/10.2307/2570634

Merton, Robert K. [1949] 1968. Social Theory and Social Structure. New York, NY: Free Press.

Meyer, John W. 2009. “Reflections: Institutional Theory and World Society.” Pp. 36-66 in World Society: The Writings of John W. Meyer, edited by G. Krucken and G. S. Drori. Oxford: Oxford University Press.

Meyer, John W., and Brian Rowan. 1977. "Institutionalized Organizations: Formal Structures as Myth and Ceremony." American Journal of Sociology 83:340-63. https ://doi .org/10. $1086 / 226550$

Murphy, Gregory B., Jeff W. Trailer, and Robert C. Hill. 1996. "Measuring Performance in Entrepreneurship Research." Journal of Business Research. 36:15-23. https ://doi .org/10. 1016/0148-2963(95)00159-X

Nee, Victor. 1989. “A Theory of Market Transition: From Redistribution to Markets in State Socialism." American Sociological Review 54:663-81. https ://doi .org/10.2307/2117747 
Nee, Victor. 1992. “Organizational Dynamics of Market Transition: Hybrid Forms, Property Rights, and Mixed Economy in China." Administrative Science Quarterly 37:1-27. https : //doi.org/10.2307/2393531

Nee, Victor. 1996. "The Emergence of a Market Society: Changing Mechanisms of Stratification in China." American Journal of Sociology 101:908-49. https://doi .org/10.1086/ 230784

Nee, Victor, and Yang Cao. 1999. "Path Dependent Societal Transformation: Stratification in Hybrid Mixed Economies." Theory and Society 28:799-834.

Nee, Victor, Jeong-han Kang, and Sonja Opper. 2010. "A Theory of Innovation: Market Transition, Property Rights, and Innovation Activity." Journal of Institutional and Theoretical Economics 166:397-425. https://doi.org/10.1628/093245610793102152

Nee, Victor, and Sonja Opper. 2007. “On Politicized Capitalism." Pp. 93-127 in On Capitalism, edited by V. Nee and R. Swedberg. Stanford, CA: Stanford University Press.

Nee, Victor, and Sonja Opper. 2010. "Political Capital in a Market Economy." Social Forces 88:2105-33. https://doi.org/10.1353/sof .2010.0039

Nee, Victor, and Sonja Opper. 2012. Capitalism from Below: Markets and Institutional Change in China. Cambridge, MA: Harvard University Press. https://doi .org/10.4159/harvard. 9780674065390

Nelson, Richard R., and Sidney G. Winter. 1982. An Evolutionary Theory of Economic Change. Cambridge, MA: Harvard University Press.

Oi, Jean C. 1992. "Fiscal Reform and the Economic Foundations of Local State Corporatism in China." World Politics 45:99-126. https : //doi .org/10.2307/2010520

Oi, Jean C. 1999. Rural China Takes Off: Institutional Foundations of Economic Reform. Berkeley, CA: University of California Press.

Owen-Smith, Jason, and Walter W. Powell. 2004. "Knowledge Networks as Channels and Conduits: The Effects of Spillovers in the Boston Biotechnology Community." Organization Science 15:5-21. https://doi .org/10.1287/orsc.1030.0054

Parish, William L., and Ethan Michelson. 1996. "Politics and Markets: Dual Transformations." American Journal of Sociology 101:1042-59. https: //doi .org/10 . 1086/230788

Peng, Yusheng. 2004. "Kinship Networks and Entrepreneurs in China's Transitional Economy." American Journal of Sociology 109:1045-74. https://doi .org/10.1086/382347

Podolny, Joel M., and James M. Baron. 1997. "Resources and Relationships: Social Networks and Mobility in the Workplace." American Sociological Review 62:673-93. https://doi. org/10.2307/2657354

Powell, Walter W., and Paul J. DiMaggio. 1991. The New Institutionalism in Organizational Analysis. Chicago, IL: University of Chicago Press.

Ruef, Martin. 2010. The Entrepreneurial Group: Social Identities, Relations, and Collective Action. Princeton, NJ: Princeton University Press.

Ruef, Martin. 2017. "Ecological and Rational Choice Models of Endogenous Change." Rationality and Society 29:55-62. https : //doi .org/10.1177/1043463116685664

Schumpeter, Joseph. 1942. Capitalism, Socialism and Democracy. London, England: Allen and Unwin.

Shleifer, Andre, and Robert W. Vishny. 1994. "Politicians and Firms." Quarterly Journal of Economics 109:995-1025. https://doi.org/10.2307/2118354

Solow, Robert. 2017. "Notes toward a Macro Version of the Nee-DellaPosta-Opper Model of Institutional Change." Rationality and Society 29:49-54. https ://doi .org/10.1177/ 1043463116685665 
Sorenson, Olav. 2017. "Entrepreneurs and Social Capital in China." Management and Organization Review 13:275-80. https://doi.org/10.1017/mor.2017.21

Tsui, Anne S., Yingying Zhang, and Xiao-Ping Chen. 2017. Leadership of Chinese Private Enterprises: Insights and Interviews. London, England: Palgrave Studies in Chinese Management.

Uzzi, Brian. 1996. “The Sources and Consequences of Embeddedness for the Economic Performance of Organizations: The Network Effect." American Sociological Review 61:67498. https://doi.org/10.2307/2096399

van de Rijt, Arnout. 2017. "Microfoundations of Institutional Change." Rationality and Society 32:160-76. https://doi.org/10.1177/1043463116685667

Vedres, Balazs, and David Stark. 2010. "Structural Folds: Generative Disruption in Overlapping Groups." American Journal of Sociology. 115:1150-90. https ://doi .org/10.1086/ 649497

Walder, Andrew. 1995. "Local Government as Industrial Firms: An Organizational Analysis of China's Transitional Economy." American Journal of Sociology 101:263-301. https: //doi.org/10.1086/230725

Walder, Andrew. 1996. "Markets and Inequality in Transitional Economies: Toward Testable Theories." American Journal of Sociology. 101:1060-73. https://doi.org/10.1086/ 230789

Walder, Andrew. 2003. "Elite Opportunity in Transitional Economies." American Sociological Review 68:899-916. https://doi .org/10.2307/1519750

Weber, Max. [1922] 1978. Economy and Society. Berkeley, CA: University of California Press.

Weber, Max. [1927] 1981. General Economic History. New Brunswick, NJ: Transaction Publishers.

Weber, Max. [1904] 2001. The Protestant Ethic and the Spirit of Capitalism. London, England: Routledge.

Williamson, Oliver E. 1985. The Economic Institutions of Capitalism. New York, NY: Free Press.

Xiao, Zhixing, and Anne S. Tsui. 2007. “When Brokers May Not Work: The Cultural Contingency of Social Capital in Chinese High-Tech Firms." Administrative Science Quarterly 52:1-31. https://doi.org/10.2189/asqu.52.1.1 
Acknowledgements: Victor Nee gratefully acknowledges grants from the John Templeton Foundation (2005-2010; 2015-2018), research assistant support from the College of Arts and Sciences at Cornell University, and the Jan Wallander and Tom Hedelius Foundation (2011-2013). We thank Michael Macy, Anne Tsui, Brett de Bary, Rachel Davis, Mario Molina, Lucas Drouhot, and David Strang for their helpful comments on an earlier draft. Victor Nee received helpful feedback on his presentation of the article at the 2017 Conference of the International Network of Analytical Sociologists in Oslo, Norway, on June 5 and 6 and the Annual Meeting of the Academy of International Business in Dubai, United Arab Emirates, from July 3 to 6. Lisha Liu and Daniel DellaPosta share equal responsibility in their contributions.

Victor Nee: Department of Sociology, Cornell University.

E-mail: victor.nee@cornell.edu.

Lisha Liu: Department of Sociology, Cornell University.

E-mail: 11733@cornell.edu.com.

Daniel DellaPosta: Department of Sociology and Criminology, Pennsylvania

State University.

E-mail: djd78@psu.edu. 